\title{
Reconhecimento da Equipe - Dia do Arquivista: Relato de Experiência
}

\author{
Santos, Suely Luzia dos; Milani, Clarice Aparecida; Vieira, Jeniffer de Oliveira; \\ Almeida, José Batista de; Azevedo, Naiza Farias de; Souza, Sandra Regina Diniz \\ Divisão Arquivo Médico do Instituto Central do HCFMUSP — suely.santos@hc.fm.usp.br
}

1. INTRODUÇÃO o presente relato de experiência tem como objetivo mostrar que práticas de humanização podem ser usadas como estratégia de gestão e qualidade nos serviços. a Divisão de Arquivo Médico do ICHC foi fundada em 1980, com a intenção de ser uma unidade de apoio, subordinada a Diretoria Executiva do $\mathrm{ICHC}$, responsável pelas atividades de guarda e gerenciamento dos prontuários médicos, bem como atividades relacionadas a recepção e atendimento de pacientes. 2. OBJETIVOS Esta ação de humanização foi implantada em outubro/2010, com a intenção de proporcionar aos colaboradores da Divisão de Arquivo Médico um momento de descontração e reconhecimento pelos serviços prestados, além do fortalecimento de laços entre os colaboradores. 3. METODOLOGIA Esta ação de humanização é realizada no dia 20 de outubro, no horário das 14:00 horas, horário que compreende maior facilidade para os colaboradores participarem. a equipe do Grupo Tático colabora na confecção de Certificados e Carta de Reconhecimento pela atividade desenvolvida, com uma mensagem que incentiva e motiva além de informações diversas de caráter educativo, auxilia na captação de brindes para sorteio nas áreas do ICHC (UEP, Serviço Social). É realizada uma dinâmica educativa a cada comemoração, proporcionando a descontração e relaxamento físico. Alem da comemoração do dia, foi estabelecido que o colaborador tenha uma folga, combinada com a chefia, sem prejuízo ao serviço. 4. RESULTADOS a Divisão de Arquivo Médico do ICHC, conta hoje com 270 colaborares. Sendo que a Seção de Arquivo de Prontuários é responsável por retirar e arquivar os prontuários para consulta ambulatorial, que em média varia entre $7 \mathrm{mil}$ a 8 mil prontuários por dia. Também responde pelas Recepções de Ambulatórios, Seção de Registro de Pronto Socorro, Seção de Informação, Seção de Matricula e Internação, Seção de Dados Médicos e Faturamento e Seção de Laudo Médico. Todas essas atividades exigem do colaborador atenção, pois se um prontuário for arquivado na numeração errada, pode causar prejuízo ao atendimento ao paciente. Diante do esforço dispensado pelos colaboradores e da necessidade de manter os funcionários motivados a diretoria da área estabeleceu criar a comemoração do dia do arquivista, com o propósito de mostrar aos funcionários que a atividade desenvolvida é de suma importância tanto para o paciente que precisa do atendimento, quanto aos médicos da instituição que fazem a pesquisa nos prontuários. Desta forma, o evento proporciona maior integração da Equipe, descontração e relaxamento físico, ativando as emoções e ampliação do contato físico com os funcionários das demais Seções da Divisão de Arquivo Médico. 5. CONCLUSÃo Acreditamos que essa ação de humanização passou a ser um estimulo aos colaboradores, tendo em vista que eles ficam aguardando o evento, questionando se terá brindes. Além de proporcionar um clima de trabalho bem mais agradável. a atitude colaborativa de alguns funcionários sofreu uma mudança considerável. Durante a comemoração sempre é divulgado os trabalhos da Rede de Humanização, onde são convidados alguns representantes para falar sobre a importância da profissão de Arquivista e das ações de humanização no ambiente hospitalar.

Santos, Suely Luzia dos; Milani, Clarice Aparecida; Vieira, Jeniffer de Oliveira; Almeida, José Batista de; Azevedo, Naiza Farias de; Souza, Sandra Regina Diniz. Reconhecimento da Equipe - Dia do Arquivista: Relato de Experiência. In: Anais do Congresso Internacional de Humanidades \& Humanização em Saúde [= Blucher Medical Proceedings, num.2, vol.1]. São Paulo: Editora Blucher, 2014. ISSN 2357-7282 DOI 10.5151/medpro-cihhs-10327 